University of Nebraska - Lincoln

DigitalCommons@University of Nebraska - Lincoln

West Central Research and Extension Center, North Platte

Agricultural Research Division of IANR

2007

\title{
Phosphorus Losses in Runoff after Application of Litter from Broilers Fed High-Available Phosphorus Corn Feed
}

David D. Tarkalson

West Central Research and Extension Center, North Platte, Nebraska, david.tarkalson@ars.usda.gov

Robert L. Mikkelsen

North Carolina State University

Follow this and additional works at: https://digitalcommons.unl.edu/westcentresext

Part of the Agriculture Commons

Tarkalson, David D. and Mikkelsen, Robert L., "Phosphorus Losses in Runoff after Application of Litter from Broilers Fed High-Available Phosphorus Corn Feed" (2007). West Central Research and Extension Center, North Platte. 1.

https://digitalcommons.unl.edu/westcentresext/1

This Article is brought to you for free and open access by the Agricultural Research Division of IANR at DigitalCommons@University of Nebraska - Lincoln. It has been accepted for inclusion in West Central Research and Extension Center, North Platte by an authorized administrator of DigitalCommons@University of Nebraska - Lincoln. 


\title{
Phosphorus Losses in Runoff after Application of Litter from Broilers Fed High-Available Phosphorus Corn Feed
}

\author{
David D. Tarkalson \\ Department of Agronomy and Horticulture, University of Nebraska- Lincoln, \\ West Central Research and Extension Center, North Platte, Nebraska \\ Robert L. Mikkelsen \\ Department of Soil Science, North Carolina State University, \\ Raleigh, North Cardina \\ Corresponding author - David D. Tarkalson, Department of Agronomy and Horticulture, \\ University of Nebraska-Lincoln, West Central Research and Extension Center, 461 West \\ University Drive, North Platte, NE 69101; email: dtarkalson2@unl.edu
}

\begin{abstract}
Recent efforts to reduce phosphorus $(\mathrm{P})$ content of corn grain fed to poultry have led to the development of low-phytic-acid corn. Research is needed to evaluate the environmental impact of the application to cropland of manure from animals fed low-phytic-acid corn. The purpose of this research was to determine P losses in runoff from a bare Piedmont soil (cecil clay loam; clayey, kaolinitic, thermic, Typic Kanhapludult) in the southeastern United States receiving surface applications of broiler litter from birds fed a low-phytic-acid corn (HAP broiler litter). The HAP litter was applied at rates of $0,8,16,33,49,66$, and $82 \mathrm{~kg} \mathrm{P} \mathrm{ha}^{-1}$. Simulated rainfall was applied at a rate of $7.6 \mathrm{~cm} \mathrm{hr}^{-1}$ on the same day the litter sources were applied to the plots. Runoff volumes were measured, and samples were collected at 5-min intervals for $30 \mathrm{~min}$ and analyzed for reactive $\mathrm{P}(\mathrm{RP})$, algal-available $\mathrm{P}$ (AAP), and total $\mathrm{P}$ (TP). Flow-weighted concentrations and mass losses of $P$ increased linearly with litter application rate $\left(r^{2}\right.$ values $\left.=0.99\right)$. Flow-weighted concentrations of RP in runoff increased from 2.2 to $15.4 \mathrm{mg} \mathrm{RP} \mathrm{L}^{-1}$, and mass loss of TP in runoff ranged from 1.3 to $7.3 \mathrm{~kg} \mathrm{P} \mathrm{ha}^{-1}$ over all application rates based on linear regression. Runoff volume losses were $47 \%$ greater after litter applications compare to the 0 application rate treatment. Reduced infiltration resulting from litter particles blocking pores in the soil surface is likely the reason for the increased runoff volumes.
\end{abstract}


Keywords: Algal-available phosphorus, broiler litter, HAP corn, reactive phosphorus, runoff, total phosphorus

\section{Introduction}

Phosphorus (P) loss to surface waters via runoff from lands receiving animal waste applications is an environmental concern because of eutrophication (Sharpley, Daniel, and Edwards 1993). The introduction of high available P (HAP) (Pioneer Hi-Bred International, Inc.) corn into animal feeds potentially offers a major advance in $\mathrm{P}$ management from animal manures. As HAP corn becomes more widely available as an animal feed, it is important to understand the environmental fate of $\mathrm{P}$ in manure and the most appropriate agronomic management practices required to optimize the value of this nutrient.

Corn and many grains used for animal feed contain most of the $\mathrm{P}$ in the form of phytic acid (myo-inositol 1,2,3,4,5,6-hexa-kisphosphate), also referred to as phytate. For example, phytate $\mathrm{P}$ represents approximately $80 \%$ of the total P contained in the seed in many corn varieties (Ravindran, Ravindran, and Sivalogan 1994). Monogastric animals such as swine and poultry digest only 10 to $20 \%$ of the phytate P because of a lack of phytase enzyme in their digestive system (Ertl, Young, and Raboy 1998). Raboy and Gerbasi (1996) developed a nonlethal corn mutant that stores most of its seed $\mathrm{P}$ as inorganic $\mathrm{P}$ rather than phytate. This corn is often referred to as HAP corn. Specifically, the mutants Lpa2-1 and Lpa11 had phytate $P$ reductions of 50 and $60 \%$, respectively, compared to traditional corn varieties. These mutants maintain the same total P content as traditional varieties by storing more $\mathrm{P}$ as inorganic $\mathrm{P}$ (Ertl, Youns, and Reboy 1998).

A typical broiler feed ration contains $65 \%$ corn and $25 \%$ soybean. By lowering the phytic acid contribution from $0.29 \%$ to $0.11 \%$ with the lowphytic-acid corn (Lpa1-1), a decrease in phytic acid of approximately $35 \%$ can be achieved assuming a typical phytic acid content of $0.38 \%$ in soybean (Ertl, Young, and Raboy 1998). The use of HAP corn as a feed source also reduces the requirement for inorganic P supplements in poultry diets. Huff et al. (1998) reported P supplements could be reduced by $21 \%$ compared with traditional corn-based diets while maintaining excellent bird growth. The introduction of HAP corn into animal feeds potentially offers a major advance in $\mathrm{P}$ management from animal manures. More digestible P in HAP corn will potentially allow animal farmers to improve their management of manure to reduce adverse environmental impacts on surrounding surface water. Because more $\mathrm{P}$ is available for 
animal uptake in HAP corn compared to conventional corn, and HAP litter has a higher N:P ratio, there is a potential for decreased risk of $\mathrm{P}$ losses from application HAP manures compared to conventional litters when applied at the same $\mathrm{N}$ application rate.

Losses of $\mathrm{P}$ in runoff following manure application to the soil surface have been found to increase (Tarkalson and Mikkelsen 2004; Edwards and Daniel 1993; Smith, Jackson, and Pepper 2001) and not increase (Bengtson, Selim, and Ricard 1998) as application rates increase. Variation in site-specific conditions and management (e.g., the physical and chemical composition of manure, soil characteristics, rainfall, and cropping management) influence the likelihood of $\mathrm{P}$ loss from a given location.

The objective of this research was to examine losses of $\mathrm{P}$ in runoff after surface application of litter derived from broiler fed HAP corn at different application rates.

\section{Methods}

\section{Research Site and Experimental Design}

Eighteen $9-\mathrm{m}^{2}$ plots (3-m by 3-m) with a 1-m border were arranged on 0.12 ha located on the North Carolina State University Lake Wheeler Farm in Raleigh, N.C. The area selected for this study had to a uniform slope (2 to $3 \%$ ) and surface soil texture (Cecil clay loam; clayey, kaolinitic, thermic, Typic Kanhapludult). The surface soil $(2.5 \mathrm{~cm})$ contained 32\% clay.

The treatments consisted of broiler litter from birds fed diets of HAP corn. The HAP litter was added to the soil surface at application rates of 0 , $8,16,33,49,66$, and $82 \mathrm{~kg} \mathrm{P} \mathrm{kg}^{-1}$. The application rates were replicated three times in a completely randomized design. The total $\mathrm{N}(\mathrm{TN})$ and TP content of the HAP litter were $22.8 \mathrm{~g} \mathrm{~N} \mathrm{~kg}^{-1}$ and $7.9 \mathrm{~g} \mathrm{P} \mathrm{kg}^{-1}$ on a dry-weight basis, respectively. The HAP litter was uniformly hand applied onto the soil surface of the plots, and rainfall simulation occurred on the same day.

A variable-rate rainfall simulator (Joerns Inc., West Lafayette, Ind.) was used to apply rainfall at a rate of $7.6 \mathrm{~cm} \mathrm{hr}^{-1}$ to a $4-\mathrm{m}^{2}$ (2-m by 2$\mathrm{m})$ plot area outlined by a steel frame inserted to a depth of $10 \mathrm{~cm}$. This rainfall rate was based on the runoff simulation protocols of the National Phosphorus Research Project (National Phosphorus Research Project 1999), and is slightly higher than the average rainfall rate for the 1-hour, 10-year return period storm in the Piedmont region of North Carolina $\left(6.4 \mathrm{~cm} \mathrm{hr}^{-1}\right)$. Runoff was intercepted at the bottom of the plot with a plastic gutter buried in the ground and directed to a buried 19-L polycarbonate collection vessel. During the 30-min rainfall event, runoff water was collected at 5-min intervals after the start of runoff, the volume recorded, and water subsampled for subsequent laboratory analysis. 


\section{Analytical Methods}

Water samples were refrigerated at $4^{\circ} \mathrm{C}$ while awaiting chemical analysis. Water samples were filtered through a $45-\mathrm{mm}$ filter and extracted for RP (Haygarth and Sharpley 2000). Algal-available P (AAP) was extracted from unfiltered samples using $0.11 \mathrm{M}$ sodium hydroxide $(\mathrm{NaOH})$ (Sharpley, Troeger, and Smith 1991), and TP was extracted from unfiltered samples using a sulfuric acid $\left(\mathrm{H}_{2} \mathrm{SO}_{4}\right)$ and ammonium persulfate $\left[\left(\mathrm{NH}_{4}\right)_{2} \mathrm{~S}_{2} \mathrm{O}_{8}\right]$ digestion (Greenberg et al. 1992). Concentrations of RP, AAP, and TP in runoff were determined using a colorimetric procedure (Murphy and Riley 1962). Mass losses of $P$ were determined for each 5-min sampling interval by multiplying the measured concentration of $\mathrm{P}$ by the recorded runoff volume during the 5-min interval. Mass losses of $\mathrm{P}$ were summed over the six 5-min intervals to give a total mass loss over the 30-min rainfall event. Measured concentrations of RP, AAP, and TP in runoff were flow-weighted by dividing the total 30-min mass losses of RP, AAP, and $\mathrm{TP}$ by the total runoff volume over the 30 -min rainfall period.

\section{Statistical Analysis}

Analysis of variance and least significant difference was used to compare the differences in runoff rates for the different HAP litter application rates. Linear regression was used to develop equations to predict RP, $\mathrm{AAP}$, and TP concentration and mass losses in runoff (dependent variables) from cropland at different surface application rates (independent variable) of HAP litter. All statistical analysis procedures were conducted using Statistix 8 (Analytical Software 2003). Significance was determined for all analysis at the 0.05 probability level.

\section{Results and Discussion}

\section{Runoff Volume and Rate}

The addition of litter at all application rates increased runoff volumes compared to the 0 application rate treatment (Figure 1). The 0 application rate treatment on average had runoff volumes $47 \%$ less than all the other litter application rate treatments. The increased runoff after surface applications was possibly due to litter particles blocking pores at the soil surface, resulting in decreased infiltration. More research is needed to verify this theory. These results are contrary to other studies that showed reduced runoff after manure applications compared to no manure (Wortmann and Walters 2006; McDowell and Sharpley 2003). However, there were some differences between this study and the other studies that may explain the discrepancies. The timing of manure application, rainfall tim- 


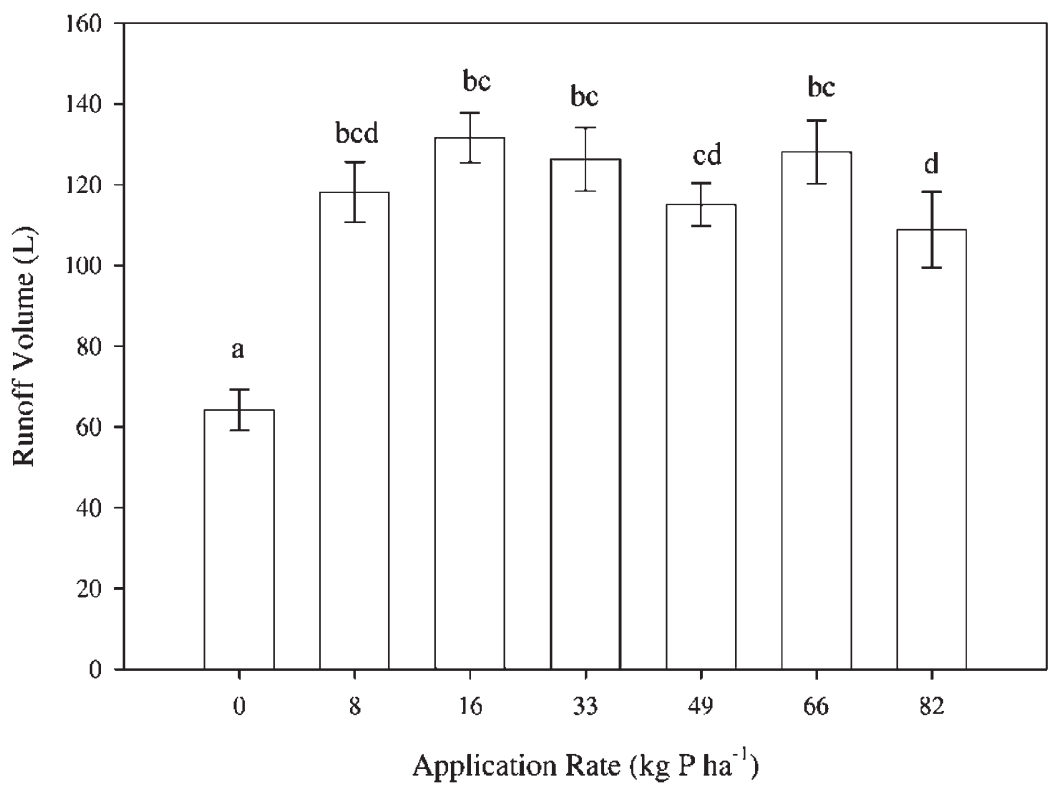

Figure 1. Runoff volume for HAP litter application rates of $0,8,16,33,49$, 66, and 82 $\mathrm{kg} \mathrm{P} \mathrm{ha}{ }^{-1}$. Data was summed over the 30 min runoff event and is the average of three replications. Columns with the same letter are not significantly different at the 0.05 probability level using LSD.

ing and rainfall intensity differed from this study compared to the other cited studies. In the study conducted by Wortmann and Walters (2006), manure had been applied (surface and incorporated) for three consecutive years prior to the initiation of the study, and the runoff was measured during natural precipitation events. This study only assessed runoff the day of application with an intense rainfall event. These studies report that the manure improved soil structure, thus increasing infiltration rates. The improved soil structure likely occurs over time as the manure has time to interact with the soil.

Runoff rate increased over time for all application rates (Figure 2). The infiltration rate during the initial stages of the rainfall event was higher because of the attraction of the water to the soil matrix, but as the rainfall event proceeded, the soil pores were filled and the infiltration decreased. Runoff rates for the 0 application rate treatment were always lower than for the other litter application rates (Figure 2).

\section{Runoff Phosphorus Concentrations and Mass Losses}

The concentrations of RP and mass losses TP in runoff over the 30min runoff event for all application rates are presented in Figure 2. Generally, concentrations of $\mathrm{RP}, \mathrm{AAP}$, and $\mathrm{TP}$ in runoff decreased over time 


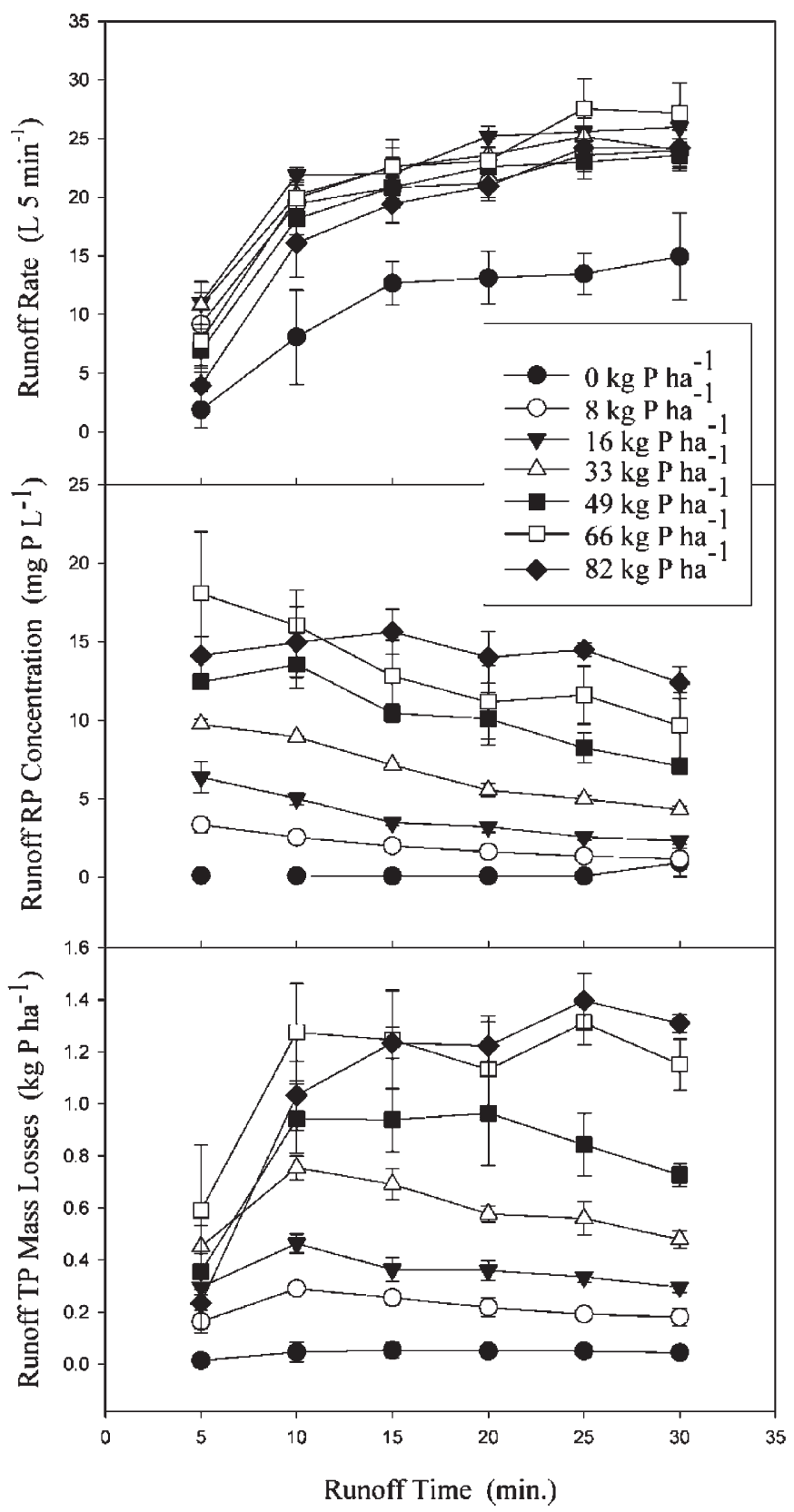

Figure 2. Runoff rate, RP concentration, and TP mass losses at each runoff time from plots treated with HAP broiler litter at rates of $0,8,16,33,49,66$, and $82 \mathrm{~kg} \mathrm{P} \mathrm{ha}^{-1}$. All values are the average of three replications. Error bars are the standard errors of the treatment means. Some standard errors are not visible because of the small standard error being masked by the size of the symbols. 


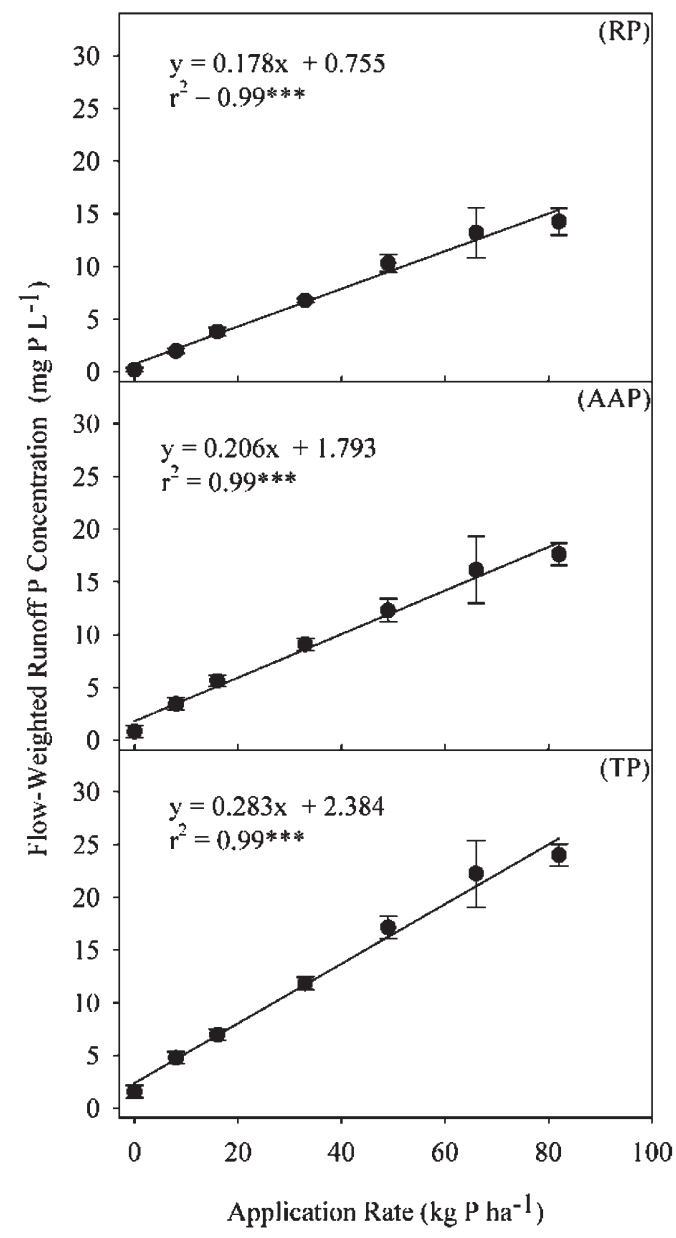

Figure 3. Relationship between surface-applied P application rates of HAP broiler litter and the reactive phosphorus (RP), algal-available phosphorus (AAP), and total phosphorus (TP) flow-weighted concentrations in runoff. Data was averaged over the 30 min runoff event. Values are the average of three replications. Error bars are the standard error of the application rate means. ${ }^{* * *}$ denotes slopes significantly different from 0 at the 0.01 probability level..

for most application rates. There was an increase in mass losses of RP, $\mathrm{AAP}$, and TP in runoff from the initiation of rainfall to the 10-min sampling time for all application rates. The mass losses of RP, AAP, and TP in runoff either stabilized or slightly decreased after the 10-min sampling time for all application rates.

The relationships between $\mathrm{P}$ application rate and flow-weighted average concentrations and cumulative mass losses of RP, AAP, and TP in runoff were all statistically significant (Figures 3 and 4). The concentra- 


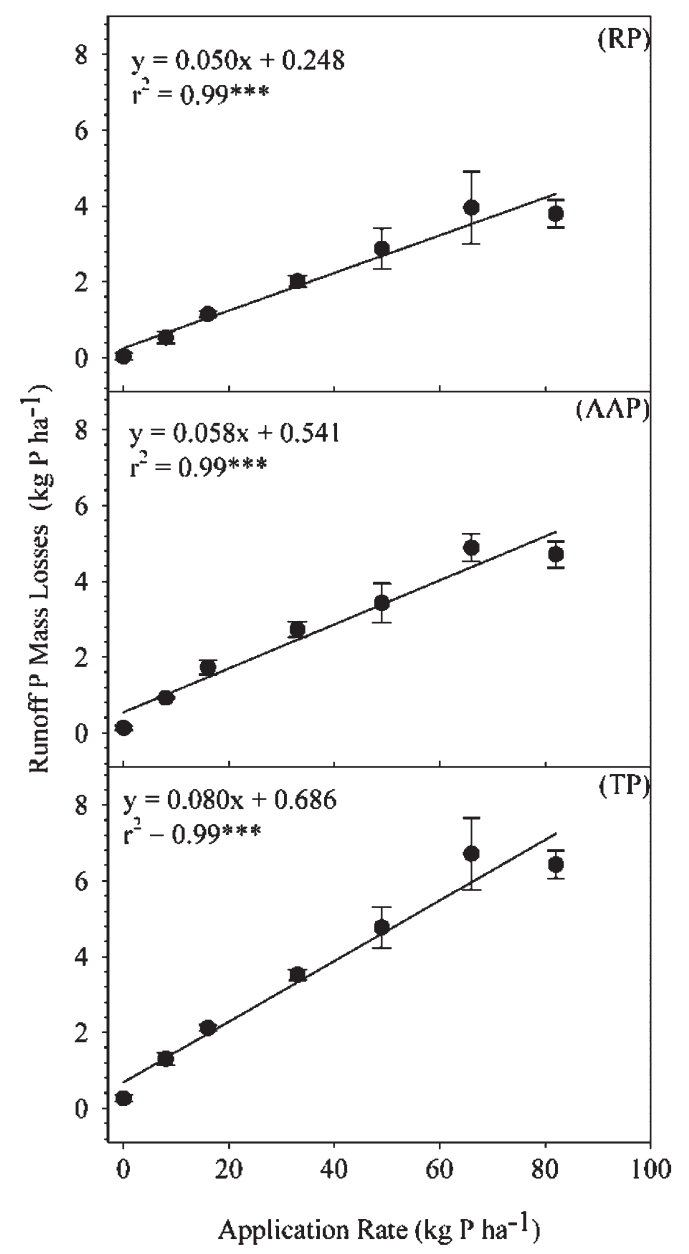

Figure 4. Relationship between surface-applied $\mathrm{P}$ application rates of HAP broiler litter and the reactive phosphorus (RP), algal-available phosphorus (AAP), and total phosphorus (TP) mass losses in runoff. Data was summed over the 30-min runoff event. Values are the average of three replications. Error bars are the standard error of the application rate means. ${ }^{* *}$ denotes slopes significantly different from 0 at the 0.01 probability level..

tions and mass losses of $\mathrm{P}$ in runoff linearly increased as application rates increased from plots receiving HAP broiler litter. Previous research has shown that high surface application rates of broiler litter (typical when application is based on the $\mathrm{N}$ requirement of crops) can result in higher runoff $\mathrm{P}$ concentrations compared to inorganic $\mathrm{P}$ fertilizer (Tarkalson and Mikkelsen 2004).

Concentrations of $\mathrm{P}$ in runoff from plots receiving HAP broiler litter at application rates of 8 to $82 \mathrm{~kg} \mathrm{P} \mathrm{ha}^{-1}$ ranged from 2.2 to $15.4 \mathrm{mg}$ 
RP L $\mathrm{L}^{-1}, 3.4$ to $18.7 \mathrm{mg}$ AAP L ${ }^{-1}$, and 4.6 to $25.6 \mathrm{mg} \mathrm{TP} \mathrm{L}^{-1}$ based on linear regression equations (Figure 3). Mass losses of $\mathrm{P}$ in runoff from plots receiving HAP broiler litter application rates of 8 to $82 \mathrm{~kg} \mathrm{P}^{-}$ ${ }^{1}$ ranged from 0.65 to $4.4 \mathrm{~kg} \mathrm{RP} \mathrm{ha}^{-1}, 1.0$ to $5.3 \mathrm{mg} \mathrm{AAP} \mathrm{ha}^{-1}$, and 1.3 to $7.3 \mathrm{~kg} \mathrm{TP} \mathrm{ha}^{-1}$ (Figure 4). Both concentration and mass losses in runoff in this study were comparable to losses from conventional broiler litter applied at the same site and under the same simulated rainfall conditions, and they were greater than inorganic fertilizer (Tarkalson and Mikkelsen, 2004).

\section{Conclusions}

The concentrations and mass losses of $\mathrm{P}$ in runoff from plots receiving HAP broiler litter at various $\mathrm{P}$ application rates were measured under a worst-case scenario (surface application onto bare soils and immediate application of rainfall). The results from this study provide an estimation of the maximum potential losses of $\mathrm{P}$ in runoff from agricultural land with similar rainfall and soil characteristics. The concentrations and mass losses of P in runoff increased as application rate increased. Implementation of selected best management practices can potentially reduce $\mathrm{P}$ losses in runoff compared to the losses reported from this study. This research suggests that intense rainfall events shortly after surface applications of manure can increase runoff volumes and rates over no application of manure, escalating $\mathrm{P}$ loss potential.

The concentration and mass losses of $\mathrm{P}$ in runoff from surface applications of HAP broiler litter were similar to conventional broiler litter applied at the same rates but higher than inorganic fertilizer (Tarkalson and Mikkelsen 2004).

\section{References}

Analytical Software. (2003) Statistix 8; Analytical Software: Tallahassee, FL.

Bengtson, R.L., Selim, H.M., and Ricaud, R. (1998) Water quality from sugarcane production on alluvial soils. Trans. ASAE, 41 (5): 1331-1336.

Edwards, D.R. and Daniel, T.C. (1993) Runoff quality impacts of swine manure applied to fescue plots. Trans. ASAE, 36 (1): 81-86.

Ertl, D.S., Young, K.A., and Raboy, V. (1998) Plant genetic approaches to phosphorus management in agricultural production. J. Environ. Qual., 27 (2): 299-304.

Greenberg, A.E., Clesceri, L.S., Eaton, A.D., and Franson, M.H. (1992) Standard Methods for the Examination of Water and Wastewater, 18th ed., part 4000; American Public Health Association: Washington D.C.

Haygarth, P.M. and Sharpley, A.N. (2000) Terminology for phosphorus transfer. J. Environ. Qual., 29 (1): 10-15. 
Huff, W.E., Moore, P.A., Jr., Waldroup, P.W., Waldroup, A.L., Balog, J.M., Huff, G.R., Rath, N.C., Daniel, T.C., and Raboy, V. (1998) Effect of dietary phytase and high available phosphorus corn on broiler chicken performance. Poultry Sci., 77 (12): 1899-1904.

McDowell, R.W. and Sharpley, A.N. (2003) Phosphorus and sediment loss in overland flow in relation to soil carbon quality. J. Environ. Qual., 32 (1): 207-214.

Murphy, L. and Riley, J.P. (1962) A modified single solution method for the determination of phosphate in natural waters. Anal. Chem. Acta., 27: 31-36.

National Phosphorus Research Project. (1999), www.sera17.ext.vt.edu

Raboy, V. and Gerbasi, P. (1996) Genetics of myo-inositol phosphate synthesis and accumulation. In Subcellular Biochemistry: Myo-inositol Phosphates, Phosphoinositides, and Signal Transduction L, Biswas, B.B. and Biswas, S. (eds.); Plenum Press: New York, Vol. 26, 257-285.

Ravindran, V., Ravindran, G., and Sivalogan, S. (1994) Total and phytate phosphorus contents of various foods and feedstuffs of plant origin. Food Chem., 50 (2): 133-136.

Sharpley, A.N., Daniel, T.C., and Edwards, D.R. (1993) Phosphorus movement in the landscape. J. Prod. Agric., 6 (4): 492-500.

Sharpley, A.N., Troeger, W.W., and Smith, S.J. (1991) The measurement of bioavailable phosphorus in agricultural runoff. J. Environ. Qual., 20 (1): 235-238.

Smith, K.A., Jackson, D.R., and Pepper, T.J. (2001) Nutrient losses by surface runoff following the application of organic manures to arable land, 2: Phosphorus. Environ. Pollut., 112 (1): 53-60.

Tarkalson, D.D. and Mikkelsen, R.L. (2004) Runoff phosphorus losses as related to phosphorus source, application method, and application rate on a Piedmont soil. J. Environ. Qual., 33 (4): 1424-1430.

Wortmann, C.S. and Walters, D.T. (2006) Phosphorus runoff during four years following composted manure application. J. Environ. Qual., 35 (2): 651-657. 